\title{
Comparison of Macro and Micro Mineral Compositions of Some Alternative Protein Sources Used in Livestock with Respect of Fish Diets Requirements in Turkey
}

\author{
Emrah KAYA $^{1 *}$, Adem KAMALAK ${ }^{1}$, Ali İhsan ATALAY ${ }^{2}$, Özer KURT ${ }^{1}$ \\ ${ }^{1}$ KSU, Faculty of Agriculture, Department of Animal Science, Kahramanmaras/Turkey \\ ${ }^{2}$ Igdir University, Faculty of Agriculture, Department of Animal Science, Igdır/Turkey
}

Received (Geliş): 29.12.2015

Accepted (Kabul): 19.02.2016

\begin{abstract}
The aim of this study was to compare the macro and micro mineral composition of some protein sources used in livestock production in Turkey. There are significant $(\mathrm{P}<0.001)$ variations among protein sources. The legume grain sources had a significant $(\mathrm{P}<0.001)$ effect on the macro and micro mineral contents. The calcium (Ca) content of L. Sativus was significantly $(\mathrm{P}<0.001)$ higher than those of legume seeds and soybean meal (SBM). On the other hand phosphorus $(\mathrm{P})$, magnesium $(\mathrm{Mg})$ and potassium $(\mathrm{K})$ contents of legume grains was significantly lower than that of SBM. The zinc $(\mathrm{Zn})$, iron $(\mathrm{Fe})$, manganese $(\mathrm{Mn})$ and copper $(\mathrm{Cu})$ contents of legume seeds were significantly lower than that of SBM. Grains from Vicia pregrina, Pisum elatius and Vicia narbonensis are deficient in calcium to meet requirement of catfish and tilapia for optimum growth. Vicia peregrina, Pisum elatius and Vicia narbonensis should be supplemented with calcium to meet the requirement for optimum growth of fish. The legume grains studied in the current experiment are deficient in phosphorus to meet requirement of catfish, rainbow trout, common carp and tilapia for optimum growth whereas legume grains are sufficient in magnesium and zinc to meet requirement of catfish, rainbow trout, common carp and tilapia for optimum growth. On the other hand the legume grains studied in the current experiment are sufficient in iron to meet requirement of catfish and rainbow trout for optimum growth whereas Latirus sativus, Vicia pregrina and Pisum elatius are deficient in iron to meet requirement of common carp. The legume grains studied in the current experiment are sufficient in manganese to meet requirement of catfish whereas the legume grains are insufficient in manganese to meet requirement of rainbow trout and common carp. Although Vicia narbonensis are sufficient in copper to meet requirement of catfish, rainbow trout, common carp, Vicia peregrina and Pisum elatius are insufficient in copper to meet requirement of catfish, rainbow trout and common carp. As a conclusion, grains from Lathyrus sativus, Vicia peregrina, Pisum elatius and Vicia narbonensis used as a alternative protein sources in fish diets should be supplemented with minerals which are deficient to obtain the optimum performance from fish.
\end{abstract}

Key Words: Fish, legume grain, macro minerals, micro minerals

\section{Türkiye’de Hayvan Beslemede Kullanılan Bazı Alternatif Protein Kaynaklarının Balıkların Besin Madde Gereksinimi Baz Alınarak Makro ve Mikro Mineral İçeriklerinin Karşılaştırılması}

ÖZET: Bu çalışmanın amacı, Türkiye'de hayvan beslemede kullanılan alternatif protein kaynaklarının makro ve mikro mineral içeriklerini karşılaştırmaktır. Protein kaynakları arasında mineral madde bakımından önemli varyasyonlar mevcuttur. Baklagil çeşidi, danelerin makro ve mikro element içeriklerini önemli derecede etkilemiş̧ir. Mürdümüğün (Lathyrus sativus), kalsiyum (Ca) içeriğginin diğer baklagil daneleri ve soya küspesinin kalsiyum içeriğinden daha yüksek olduğu bulunmuştur. Diğer taraftan, baklagil tohumlarının fosfor $(\mathrm{P})$, magnezyum $(\mathrm{Mg})$ ve potasyum $(\mathrm{K})$ içerikleri soya küspesinden daha düşük bulunmuştur. Baklagil tohumlarının çinko $(\mathrm{Zn})$, demir $(\mathrm{Fe})$, manganez $(\mathrm{Mn})$ ve bakır $(\mathrm{Cu})$ içerikleri de soya küspesinden daha düşük bulunmuştur. Culban (Vicia pregrina), yabani bezelye (Pisum elatius) ve koca fĭg (Vicia narbonensis) tohumları kalsiyum içeriği bakımından yayın balığı ve tilapiaların optimum büyümeleri için yeterli değildirler. Bu yüzden, culban (Vicia pregrina), yabani bezelye (Pisum elatius) ve koca fiğ (Vicia narbonensis) tohumları kalsiyum bakımından desteklenmelidir. Bu çalışmada kullanılan baklagil daneleri fosfor içeriği bakımından yayın balığı, gökkuşağı alabalığı, pullu sazan ve tilapiaların optimum büyümesi için yeterli olmamasına rağmen, baklagil daneleri magnezyum ve çinko bakımından yayın balığı, gökkuşağı alabalı̆̆ı, pullu sazan ve tilapia balıklarının optimum büyümesi için yeterlidir. Diğer taraftan bu çalışmada kullanılan baklagil daneleri demir bakımından yayın balığı ve gökkuşağı alabalıkların optimum büyümeleri için yeterli olmasına rağmen mürdümük, culban ve yabani bezelye pullu sazan balıklarının ihtiyacını karşılamada yetersizdir. Bu çalışmada kullanılan baklagil daneleri manganez bakımından yayın balıklarııı ihtiyacını karşılamada yeterli olmasına rağmen, baklagil daneleri manganez bakımından gökkuşağı alabalığı ve pullu sazan balıklarının ihtiyaçlarını karşılamada yetersizdir. Koca fiğ yayın balığı, gökkuşağı alabalığı ve pullu sazan balıklarının bakır ihtiyacını karşılamada yeterli iken, culban ve yabani bezelye yayın balığı, gökkuşağı alabalığı ve pullu sazan balıklarının bakır ihtiyacını karşılamada yetersizdir. Sonuç olarak, alternatif protein kaynağı olarak kullanılan mürdümük, culban ve koca fiğin balıklarda optimum performans elde etmek için eksik olduğu minerallerce zenginleştirilmesi gereklidir.

Anahtar Kelimeler: Baklagil dane, balık, makro mineral, mikro mineral 


\section{INTRODUCTION}

It is well known that feedstuffs have important role for fish in providing with energy, protein and mineral for growth. Recently locally available legume grains were used in livestock nutrition to meet their protein and amino acid requirements due to less expensive protein and amino acid sources compared with soybean and fish meal (Karaman et al., 2009; Büyükçapar and Kamalak, 2010a, b; Ozkan et al. 2011). However the mineral content of locally available legume grains was ignored by researches and there is limited research on the macro and micro mineral contents of locally available legume grains such as Lathyrus sativus, Vicia peregrina, Pisum elatius and Vicia narbonensis. The minerals have important roles in the formation of skeletal structure, electron transfer, regulation of acidbase equilibrium, and osmoregulation. Minerals are also important components of hormones and enzymes, and they activate enzymes (NRC, 1993). The determination of mineral contents of feedstuffs used fish nutrition allow to make more accurate decision in preparation of diets to achieve the optimum performance of fish Therefore, the aim of this study was to compare the macro and micro mineral contents of Lathyrus sativus, Vicia peregrina, Pisum elatius and Vicia narbonensis seeds used in fish nutrition with respect of some fish requirement.

\section{MATERIAL and METHODS}

\section{Protein sources}

In the current study, legume grains from Lathyrus sativus, Vicia peregrina, Pisum elatius and Vicia narbonensis were hand harvested from plots established in the experiment units of natural pasture at seeding stage in Kahramanmaras, Turkey in September, 2007. The grain samples were shade-dried and milled to pass through a $1 \mathrm{~mm}$ sieve for subsequent analysis. The commercially available soybean meal obtained from a feed company (Gürdal Feed Company, Kahramanmaras, Turkey) were used as standard protein sources to compare the protein sources from legume grains. The protein and amino acids content of these legume grains from Lathyrus sativus, Vicia peregrina, Pisum elatius and Vicia narbonensis were previously investigated by Ozkan et al. (2011).

\section{Chemical Analysis}

Dry matter (DM) contents of protein sources were determined by drying the samples at $105{ }^{\circ} \mathrm{C}$ overnight (AOAC, 1990). Legume grain samples were digested with $\mathrm{HNO}_{3} / \mathrm{HClO}_{4}$ mixture for $\mathrm{P}, \mathrm{K}, \mathrm{Ca}, \mathrm{Mg}, \mathrm{Fe}, \mathrm{Mn}$, $\mathrm{Zn}$ and $\mathrm{Cu}$ (Jones and Case, 1990). The total $\mathrm{P}$ was determined by colorimetric vanadomolybophosphoric acid method (Kuo, 1996) and the total concentrations of $\mathrm{K}, \mathrm{Ca}, \mathrm{Mg}, \mathrm{Fe}, \mathrm{Mn}, \mathrm{Zn}$ and $\mathrm{Cu}$ were determined using atomic absorption spectrophotometer. The amount of macro and micro mineral contents was expressed as $\mathrm{g} / \mathrm{kg}$ DM. All chemical analyses were carried out in duplicate.

Data on macro and micro mineral contents of protein sources were subjected to one way of ANOVA using GLM of SPSS for Windows (2002). Significance between individual means was identified using the Tukey's Multiple Range test. Mean differences were considered significant at $\mathrm{P}<0.05$. Standard errors of means were calculated from the residual mean square in the analysis of variance. As a complement of ANOVA procedure, principal components analysis (PCA) was performed using mineral composition as variables and legume grains as classification criterion. The PCA analysis allows detection of the degree of association between variables by means of their relative position in a multivariate space, which is reduced to orthogonal directions of maximum variance in the original data (Afifi and Clark, 1996). The biplot display proposed by Gabriel (1971) was used. Data were analyzed using the SYSTAT 10 statistical software.

\section{RESULTS and DISCUSSION}

The macro mineral compositions of legume grains and soybean meal used in livestock production in Turkey are presented in Table 1 . The Ca content of Latirus sativus was significantly $(\mathrm{P}<0.001)$ higher than those of legume seeds and SBM. On the other hand P, $\mathrm{Mg}$ and $\mathrm{K}$ contents of legume grains was significantly lower than that of SBM.

Although calcium and phosphorus are directly involved in the development and maintenance of skeletal system and participate in several physiological processes, the dietary supply of phosphate is more critical than that of calcium since fish must effectively absorb, sore, mobilize, and conserve phosphate in both freshwater and see water environments (NRC, 1993). Grains from Vicia pregrina, Pisum elatius and Vicia narbonensis are deficient in calcium to meet requirement of catfish and tilapia for optimum growth since catfish and tilapia reared in calcium free water require 0.45 percent and 0.7 percent in diet respectively, for optimum growth (Robinson et al., 1986, 1987). Vicia peregrina, Pisum elatius and Vicia narbonensis should be supplemented with calcium to meet the requirement for optimum growth of fish.

The legume grains studied in the current experiment are deficient in phosphorus to meet requirement of catfish, rainbow trout, common carp and tilapia for optimum growth since catfish, rainbow trout, common carp and tilapia require $0.45,0.6,0.6$ and 0.5 percent of phosphorus in diet. It is well known that deficiency of phosphorus will result in poor growth, low feed efficiency and poor bone mineralization in most fish (NRC, 1993). Therefore grains from Lathyrus sativus, Vicia pregrina, Pisum elatius and Vicia narbonensis should be supplemented with phosphorus to meet the requirement for optimum growth of fish. 
Table 1. The macro mineral compositions of legume grains and soybean meal used livestock nutrition in Turkey

\begin{tabular}{|l|l|l|l|l|l|l|l|}
\hline \multirow{2}{*}{ Macro (\%) } & \multicolumn{9}{|c|}{ Sources } & \multicolumn{1}{c|}{} \\
\cline { 2 - 9 } & L.sativus & V. pregrina & P. elatius & V. narbonensis & SBM & SEM & Sig. \\
\hline $\mathrm{Ca}$ & $0.069^{\mathrm{a}}$ & $0.025^{\mathrm{bc}}$ & $0.022^{\mathrm{c}}$ & $0.024^{\mathrm{bc}}$ & $0.031^{\mathrm{b}}$ & 0.0212 & $* * *$ \\
\hline $\mathrm{P}$ & $0.354^{\mathrm{bc}}$ & $0.268^{\mathrm{c}}$ & $0.434^{\mathrm{b}}$ & $0.369^{\mathrm{b}}$ & $0.762^{\mathrm{a}}$ & 0.0277 & $* * *$ \\
\hline $\mathrm{Mg}$ & $0.099^{\mathrm{b}}$ & $0.085^{\mathrm{c}}$ & $0.088^{\mathrm{c}}$ & $0.086^{\mathrm{c}}$ & $0.155^{\mathrm{a}}$ & 0.0022 & $* * *$ \\
\hline $\mathrm{K}$ & $1.019^{\mathrm{c}}$ & $0.914^{\mathrm{d}}$ & $1.265^{\mathrm{b}}$ & $1.277^{\mathrm{b}}$ & $2.855^{\mathrm{a}}$ & 0.0109 & $* * *$ \\
\hline
\end{tabular}

${ }^{a b c}$ Row means with common superscripts do not differ $(\mathrm{P}>0.05)$; SEM - Standard error mean; Sig. - significance level, SBM - Soybean meal, *** $\mathrm{P}<0.001$.

It is well known that magnesium has role as a cofactor in many enzymatic reactions in intermediary metabolism. Magnesium also plays an important role in respiratory adaptation of freshwater fish (Houston, 1985). However magnesium deficiency may result in anorexia, reduced growth, lethargy and reduced tissue magnesium content in fish (NRC, 1993). The legume grains studied in the current experiment are sufficient in magnesium to meet requirement of catfish, rainbow trout, common carp and tilapia for optimum growth since catfish, rainbow trout, common carp and tilapia require $0.04,0.05,0.05$ and 0.06 percent of magnesium in diet (NRC, 1993). The legume grains studied in the current experiment are also sufficient in potassium to meet requirement of rainbow trout, pacific salmon for optimum growth since rainbow trout, pacific salmon require 0.7 and 0.8 percent of potassium in diets (NRC, 1993). However the deficiency sign of potassium is very difficult to produce since fish readily absorb potassium from surrounding aquatic medium.

The micro mineral compositions of legume grains and soybean meal used in livestock production in Turkey are given in Table 2. The $\mathrm{Zn}, \mathrm{Fe}, \mathrm{Mn}$ and $\mathrm{Cu}$ contents of legume seeds were significantly lower than that of SBM.

The legume grains studied in the current experiment are sufficient in terms of Zinc to meet requirement of catfish, rainbow trout, common carp and tilapia for optimum growth since catfish, rainbow trout, common carp and tilapia require 20,30,30 and $20 \mathrm{mg}$ of Zinc in $1 \mathrm{~kg}$ of diets respectively.

Table 2. The micro mineral compositions of legume grains and soybean meal used livestock nutrition in Turkey

\begin{tabular}{|c|c|c|c|c|c|c|c|}
\hline \multirow{2}{*}{$\begin{array}{c}\text { Micro } \\
(\mathrm{mg} / \mathrm{kg} \mathrm{DM})\end{array}$} & \multicolumn{5}{|c|}{ Sources } & \multirow[b]{2}{*}{ SEM } & \multirow[b]{2}{*}{ Sig } \\
\hline & L. sativus & V. pregrina & P.elatius & V.narbonensis & SBM & & \\
\hline $\mathrm{Zn}$ & $26.70^{d}$ & $28.94^{\mathrm{c}}$ & $21.45^{\mathrm{e}}$ & $31.41^{\mathrm{b}}$ & $50.08^{a}$ & 0.4353 & $* * *$ \\
\hline $\mathrm{Fe}$ & $76.60^{d}$ & $124.60^{\mathrm{c}}$ & $93.85^{d}$ & $175.21^{\mathrm{b}}$ & $210.60^{\mathrm{a}}$ & 7.2530 & $* * *$ \\
\hline $\mathrm{Mn}$ & $7.74^{\mathrm{b}}$ & $7.71^{\mathrm{a}}$ & $4.43^{b}$ & $7.74^{\mathrm{b}}$ & $23.80^{\mathrm{a}}$ & 3.5932 & $* *$ \\
\hline $\mathrm{Cu}$ & $4.20^{c}$ & $2.63^{d}$ & $2.62^{d}$ & $7.36^{\mathrm{b}}$ & $14.97^{\mathrm{a}}$ & 0.0019 & $* * *$ \\
\hline
\end{tabular}

$\mathrm{a}^{\mathrm{c}}$ Row means with common superscripts do not differ $(\mathrm{P}>0.05)$; SEM - Standard error mean; Sig. - significance level, SBM - Soybean meal, *** $\mathrm{P}<0.001$.

Iron is an essential element which is found in the body mainly in the complex from bound to proteins such as heme compounds (hemoglobin and myoglobin), heme enzymes (cytochromes, catalese etc). Iron has a role in the cellular respiratory process through its oxidation-reduction activity and electron transfer (NRC, 1993). The legume grains studied in the current experiment are sufficient in terms of iron to meet requirement of catfish and rainbow trout for optimum growth since catfish and rainbow trout require 30 and $60 \mathrm{mg}$ of iron in $1 \mathrm{~kg}$ of diets respectively whereas Latirus sativus, Vicia pregrina and Pisum elatius are deficient in iron to meet requirement of common carp since common carp requires $150 \mathrm{mg} / \mathrm{kg}$ of diet (NRC, 1993).

The legume grains studied in the current experiment are sufficient in terms of manganese to meet requirement of catfish whereas the legume grains are insufficient in manganese to meet requirement of rainbow trout and common carp since rainbow trout and common carp require $13 \mathrm{mg}$ of manganese in $1 \mathrm{~kg}$ diet $(\mathrm{NRC}, 1993)$.
Although Vicia narbonensis are sufficient in terms of copper to meet requirement of catfish, rainbow trout, common carp, Vicia peregrina and Pisum elatius are insufficient in copper to meet requirement of catfish, rainbow trout and common carp since catfish, rainbow trout and common carp require 5, 3 and $3 \mathrm{mg}$ copper in 1 $\mathrm{kg}$ diet respectively (NRC, 1993).

The analysis of the first two principal components using legume grain classification criterion is given in Figure 1. First two components explained $92.91 \%$ of the total variation. The variables $\mathrm{P}, \mathrm{Mg}, \mathrm{K}, \mathrm{Zn}, \mathrm{Fe}, \mathrm{Mn}$ and $\mathrm{Cu}$ showed the highest factor loading: $-0.929,-0.946,-0.981$, $.0 .969,0.839,0.929$ and 0.980 , respectively, explaining $77.59 \%$ of the variability among legume grains through the first component (PC I). The variables $\mathrm{Ca}$ showed the highest factor loading: 0.967 explaining $15.326 \%$ of the variability among legume grains through the second component (PC II). The principal component analysis allowed better understanding of the complex correlations among the parameters related to macro and micro mineral 
composition of legume grains. As can be seen from Figure 1 there is no significant correlation between $\mathrm{Ca}$ and other minerals whereas there is significant correlation among other minerals.

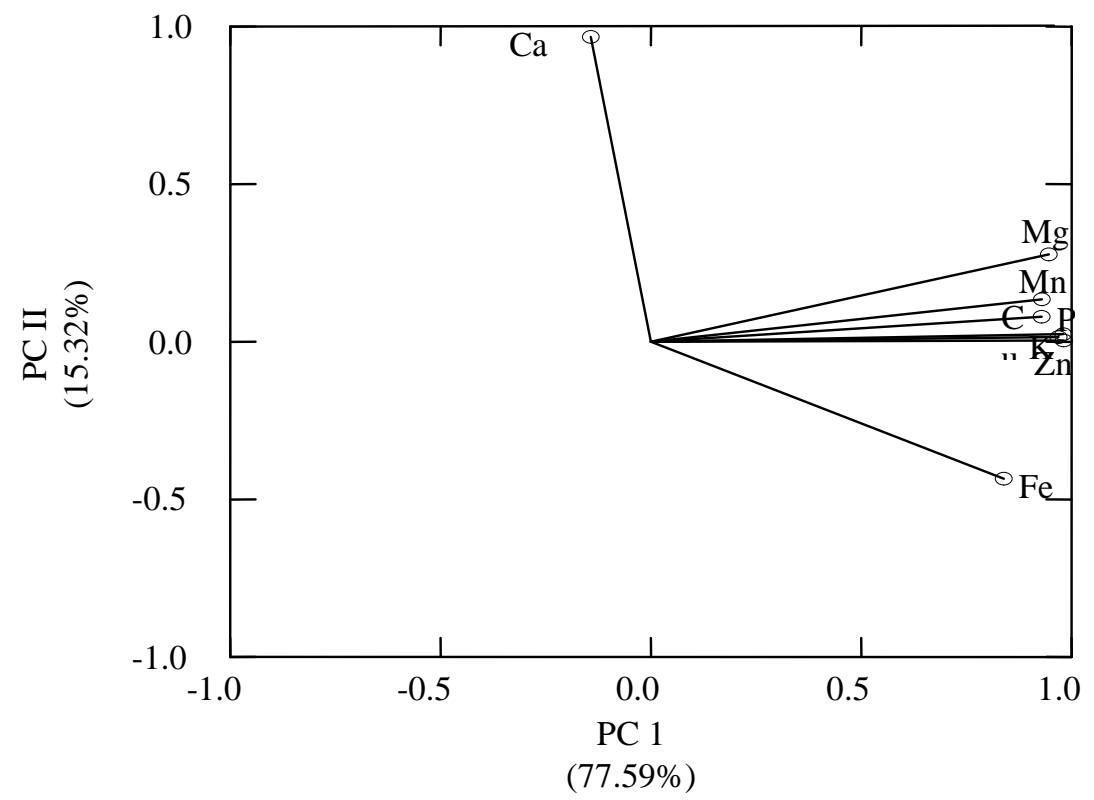

Figure 1. The analysis of the first two principal components using legume grains classification criterion

\section{CONCLUSION}

As a conclusion, grains from Lathyrus sativus, Vicia peregrina, Pisum elatius and Vicia narbonensis used as alternative protein sources in fish diets should be supplemented with minerals which are deficient to obtain the optimum performance from livestock.

\section{REFERENCES}

Afifi, A.A., Clark, V. 1996. Computer-aided multivariate analysis. 3rd Edn. pp. 455. (Lifetime Learning Publications: Belmont, California).

AOAC. 1990. Official Method of Analysis. 15th ed., pp. 69-88, Association of Official Analytical Chemist, Washington, DC, USA.

Büyükçapar, H.M., Kamalak, A. 2010a. Nutritive value of wild pea (Pisum elatius) seed as a dietary protein source for fingerlings of mirror carp (Cyprinus carpio). The Israeli Journal of Aquaculture - Bamidgeh 62(4): 272-280.

Büyükçapar, H.M., Mezdegi, M.I., Kamalak, A. 2010b. Nutritive value of narbon bean (Vicia narbonensis) seed as ingredient in practical diet for tilapia (Oreochromis niloticus) fingerlings. Journal of Applied Animal Research, 37(2):253-256.

Gabriel, K.R. 1971. The biplot graphic display of multivariate matrices with application to principal component analysis. Biometrika, 58(3):453-467.

Houston, A.H. 1985. Erythrocytic magnesium in freshwater fishes. Magnesium, 4(2-3): 106-128.
Jones J.B., Case, V.W. 1990. Sampling, handling and analyzing plant tissue samples. In, Westerman, R.L (Ed): Soil testing and plant analysis. Third edition. SSSA, Madison, WI.

Karaman, M., Canogulları, S., Baylan, M., Kamalak, A. 2009. Nutritive value of culban (Vicia peregrine) seed as dietary protein source for Japanese quail (Coturnix coturnix japonica). Journal of Animal and Veterinary Advances, 8(5):839-842.

Kuo, S. 1996. Phosphorus. In, D.L. Sparks (Ed): Methods of soil analysis: Chemical methods. Part 3, 869-921, SSSA, Madison, WI.

NRC. 1993. Nutrient Requirements of Fish. National Research Council, National Academy Press, Washington DC, $114 \mathrm{pp}$.

Ozkan, C.O., Atalay, A.I., Guven, I., Kaya, E., Sagocak, A. 2011. Crude protein and amino acid compositions of some protein sources used livestock production in south of Turkey. Asian Journal of Animal and Veterinary Advances, 6(7): 750-753.

Robinson, E.H., Rawles, S.D., Brown, P.B., Yette, H.E., Greene, L.W. 1986. Dietary calcium requirement of channel catfish (Ictalurus punctatus), reared in calcium-free water. Aquaculture 53(3-4): 263-270.

Robinson, E.H., LaBomascus, D., Brown, P.B., Linton, T.L. 1987. Dietary calcium and phosphorus requirements of Oreochromis aureus reared in calcium-free water. Aquaculture, 64(4): 267-276.

SPSS, 2002. SPSS for Windows. Release 11.5.0. SPSS Inc. Chicago, USA. 2002 